\title{
Factors Affecting Inward FDI Employment in the U.S. Economy: An Empirical Evidence
}

\author{
Lucyna Kornecki \\ Embry-Riddle Aeronautical University, Daytona Beach, Florida, USA \\ E. M. Ekanayake \\ Bethune-Cookman University, Daytona Beach, Florida, USA
}

\begin{abstract}
This research paper centers on factors affecting inward foreign direct investment (FDI) employment in the U.S. economy. The introductory part of this paper focuses on an economic analyzes of inward FDI flow and employment, by industry and states. The empirical part of this research investigates state-based factors affecting the inward FDI employment among 50 states of the United States. This study uses annual data for the period of time from 1997 to 2007 and identifies several state-specific determinants of FDI employment. The results indicate that the major factors exerting positive impact on inward US FDI employment are: real wages, infrastructure, unionization level, educational attainment, FDI stock, and manufacturing density. In addition, the results show that gross state product growth rate and real per capita taxes have negative impact on FDI employment. Surprisingly, the share of scientists and engineers in the workforce has an unexpected negative sign. Our findings indicate the importance of selected variables in evaluating the effects of FDI flow on state employment.
\end{abstract}

Keywords: foreign direct investment (FDI), panel least squares estimates, employment determinants

\section{Introduction}

Inward FDI represents an integral part of the U.S. economy. Foreign companies and their U.S. subsidiaries generate enormous economic benefits for the American economy and bring billions of investment dollars into the United States, create thousands of in-sourced American jobs, and highlight the importance of the U.S. market for foreign companies.

The United States continues to be the leading destination for foreign direct investment and the leading investor in other economies. The United States has been a very attractive investment destination due to its low-risk profile as compared to other leading global economies. Kearney’s index ranks world inward FDI and reveals FDI flows and the factors that drive corporate decisions to invest abroad. The major finding in Kearney's 2010 FDI report indicates that China and United States are the most attractive FDI locations in the world and have achieved unprecedented levels of investor confidence (Retrieved from http://www.atkearney.com/gbpc/foreign-direct-investment-confidence-index).

Lucyna Kornecki, Ph.D., Department of Economics, Finance, and Information System, College of Business, Embry-Riddle Aeronautical University.

E. M. Ekanayake, Ph.D., Department of Business Administration, School of Business, Bethune-Cookman University.

Correspondence concerning this article should be addressed to Lucyna Kornecki, 600 S. Clyde Morris Blvd. Daytona Beach, FL 32114, USA. E-mail: korneckl@erau.edu. 
The United States remains a strong FDI magnet in the world economy. Recently, China, India, and Brazil made the top spots of Kearney's FDI confidence index ${ }^{1}$.

\section{Inward US FDI Flow and Employment}

Over the last two decades, the U.S. has attracted more inflows of FDI than any other country, what positive contributed to the U.S. output growth (Asheghian, 2004). The key factor that sustained the economic expansion was the ability of the U.S. to attract capital inflows from abroad. The economic expansion in the U.S. has been sustained by the willingness of foreign investors to provide capital. The foreign capital was responsive to the U.S. business cycle over analyzed period of time showing decline in inward FDI and increase in outflow FDI during recessionary economy.

Most of the foreign direct investment in the United States during 1997-2010, based on the averaged data, entered the manufacturing industry. The FDI inflow in manufacturing industry reached an average of 33\% of the total foreign flows, followed by finance $16 \%$, wholesale trade $10 \%$, information $7 \%$, and depository institution 6\% (Retrieved from http://www.bea.gov/international/di1fdibal.htm).

Most US FDI flow during 1980-2010, originated from Europe (78\%) and Asia and Pacific region (16\%). Most European foreign flows came from the developed countries, such as: United Kingdom, Netherlands, Canada, Germany, France, Japan, and Switzerland. Inward FDI flow from Europe in the 1980s took place as a result of stagnating European economy. The highest inward FDI flow from the U.K. reflects a long-standing historical tie with the United States and a reluctance to invest into the new developing European markets of Eastern Europe (see Figure 1).

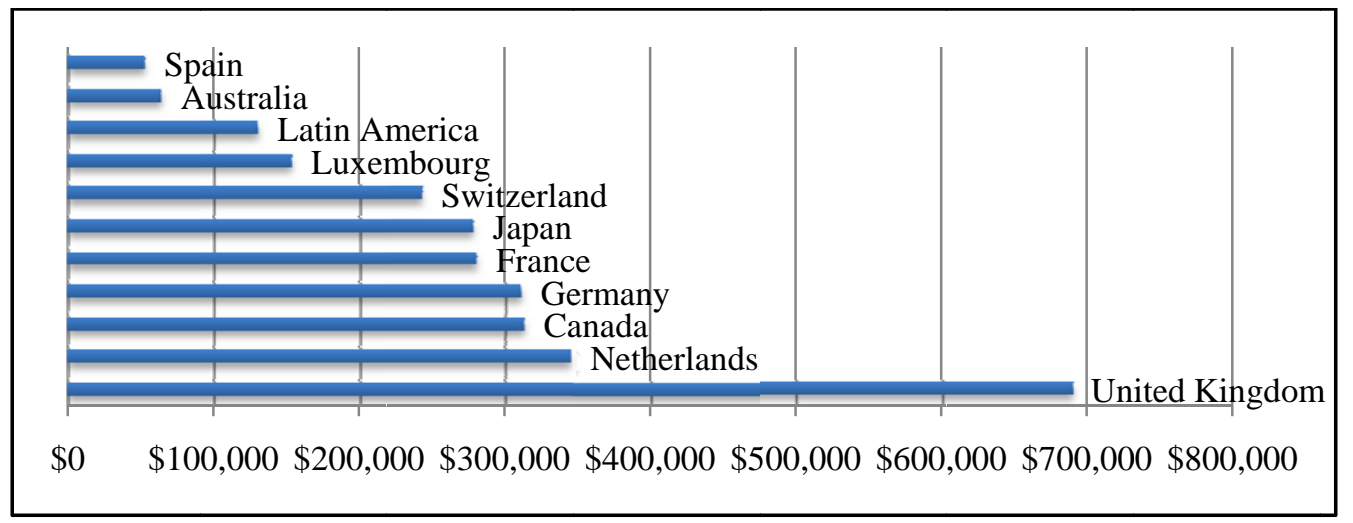

Figure 1. US Inward FDI flow by contributing country, in USD millions 1980-2010. Source: Bureau of Economic Analysis (2012a).

The U.S. economy remains a prime destination for foreign direct investment. Foreign companies investing in U.S. businesses, not only provide jobs, but also relatively high-paying jobs. Compensation per employee at U.S. affiliates of foreign firms has consistently been higher than in other U.S. firms. Workers at majority-owned U.S. affiliates of foreign companies receive 30\% higher pay than non-FDI supported jobs (Payne \& Yu, 2011). Encouraging more FDI and expanding the number of countries investing in the United States can lead potentially to higher economic growth and create new, high-paying jobs. During the last 10 years, majority-owned U.S. affiliates of foreign companies have employed between five to six million workers

${ }^{1}$ Kearney FDI confidence index (Retrieved from http://www.atkearney.com/gbpc/foreign-direct-investment-confidence-index). 
and supported two million of manufacturing jobs. FDI-supported manufacturing jobs tend to be more stable over economic recessions than domestic manufacturing jobs (Payne \& Yu, 2011).

US FDI employment between 1980 and 2009 was increasing systematically reaching the highest pick of $6,268.300$ in the year of 2000 and then declining to 5,279.700 in the year of 2009. FDI employment in manufacturing followed similar path reaching the pick of 2,705.400 in the year of 2000 declining to 1,963.800 in the year of 2009. In 2009, leading manufacturing employment was followed by retail trade employment, the wholesale trade employment, finance, and information employment.

The leading states in foreign direct investment employment are: California, Texas, Ohio, Pennsylvania, Illinois, North Carolina, New York, and New Jersey. Many foreign investors choose the southern part of the U.S. as a desirable location for their FDI. The southern U.S. states has become more aggressive in recruiting foreign investment by providing incentives to attract investments and communicating the unique advantages they offer to foreign companies. Many southern states have been successful in improving their economies and providing new employment opportunities by offering the incentives attracting foreign capital (Borstorff, Collum, \& Newton, 2009). Southern states invite large industrial employers in order to continue the evolution from an agricultural economy to a manufacturing economy. Tennessee, Alabama, Georgia, Kentucky, South Carolina, and Texas have welcomed foreign automakers with numerous incentives.

U.S. affiliates of foreign companies in the manufacturing industry are the largest contributor of FDI employment in the U.S. economy. In 2009, manufacturing employment accounted for $36.3 \%$ of total FDI employment. The next large industry outside the manufacturing for employment by U.S. affiliates of foreign companies was retail trade. The retail trade industry accounted for $10.9 \%$ of total FDI employment, followed by wholesale $9.7 \%$ along with finance and information consecutively accounting for $6.8 \%$ and $6.4 \%$ of total FDI employment (see Table 1).

Table 1

US FDI Employment (in Thousands) by Industry, as Percent of Total FDI Employment

\begin{tabular}{|c|c|c|c|c|c|c|c|c|c|c|c|c|}
\hline Year & 1997 & 1998 & 1999 & 2001 & 2002 & 2003 & 2004 & 2005 & 2006 & 2007 & 2008 & 2009 \\
\hline Manufacturing & 43.4 & 45.1 & 43.4 & 40.4 & 36.8 & 39.2 & 38.0 & 37.3 & 37.3 & 36.4 & 36.3 & 36.3 \\
\hline Wholesale trade & 9.8 & 9.2 & 8.7 & 9.4 & 8.5 & 9.7 & 10.3 & 10.4 & 10.8 & 11.1 & 9.9 & 9.7 \\
\hline Retail trade & 13.1 & 12.1 & 12.3 & 12.0 & 9.6 & 11.8 & 12.4 & 11.3 & 10.9 & 9.2 & 10.4 & 10.9 \\
\hline Information & 5.6 & 4.8 & 5.7 & 5.0 & 3.9 & 5.5 & 5.2 & 5.5 & 5.7 & 5.6 & 6.0 & 6.4 \\
\hline Finance & 4.3 & 4.2 & 4.4 & 5.2 & 3.8 & 2.0 & 4.8 & 4.7 & 4.9 & 7.1 & 7.8 & 6.8 \\
\hline Real estate & 0.8 & 0.7 & 0.9 & 0.7 & 0.6 & 0.7 & 1.1 & 0.9 & 0.8 & 0.7 & 0.6 & 0.7 \\
\hline Services & 1.6 & 1.9 & 1.9 & 3.1 & 2.7 & 3.2 & 3.4 & 3.8 & 3.8 & 4.3 & 4.2 & 4.3 \\
\hline Other industries & 21.3 & 21.9 & 22.7 & 24.3 & 23.4 & 26.1 & 24.9 & 26.0 & 25.7 & 25.7 & 24.9 & 25.1 \\
\hline
\end{tabular}

Note. Bureau of Economic Analysis, Comprehensive Financial and Operating Data Archive, Tables F7 and G7 for years 1999-2009 (Retrieved from http://www.bea.gov/international/di1fdiop.htm).

\section{Literature Review}

The inflow of FDI increased rapidly during the last two decades in almost every region of the world. A number of empirical studies on the role of FDI in host countries suggest that FDI is an important source of capital, complements domestic private investment, and is usually associated with new job opportunities and enhancement of technology transfer, and boosts overall economic growth in host countries (Chowdhury \& Mavrotas, 2006). 
Literature review indicates that there was an absence of empirical work on the location determinants of FDI across all states. Carlton (1983) concluded that economists know very little about the location determinants of new business location of manufacturing FDI in the United States. Studies by Heller and Heller (1974), Wilkins (1979), Suzman (1979), and Williams and Brinker (1985) examined a specific states (regions) and focused on quantifying the size and scope of FDI and identifying possible reasons for the investment (Axarloglou, Casey, \& Han, 2006). Little (1978), Luger and Shetty (1985), Glickman and Woodward (1987), and Coughlin (1990) have attempted to analyze empirically the determinants of the location of FDI throught the United States (Axarloglou, Casey, \& Han, 2006).

The current research in the U.S. explains the pattern at the state or county level of FDI in relation to the new investment. Economic size, labor force quality, agglomeration and urbanization economies, and transportation, infrastructure are found to positively affect the location of new foreign-owned plants, while, unit labor costs and taxes are found to deter new plants.

Comparing regions, current results reveal that the key advantages of the southeast region stem from relatively high manufacturing density and low taxes. Foreign-owned manufacturing associated with new plants has been playing a larger role in the U.S. economy, especially in the southeast region. Comparing urban with rural counties, it was found that nearly all the explanatory variables are more favorable for urban counties. For example, the labor force is relatively more productive and skilled in urban than in rural counties.

The following analysis focus on the importance of FDI for economic development at the state level: Carlton (1983), Bartik (1985), and Suger and Shetty (1985). Cletus, Terza, and Arromdee (1987) developed a Conditional Logit Model (CLM) of the foreign firm's U.S. investment location decision (Cletus, Terza, \& Arromdee, 1987). The conditional logit model of the location decision of foreign firms investing in manufacturing facilities in the United States used annual data for the 1981-1983 period. The study found evidence that states with higher per capita incomes, higher densities of manufacturing activity, higher unemployment rates, higher unionization rates, more extensive transportation infrastructures, larger promotional expenditures attracted relatively more foreign direct investment. In addition, higher wages and higher taxes deterred foreign direct investment inflows (Cletus, Terza, \& Arromdee, 1987).

Axarloglou and Pournarakis (2007) investigated the impact of FDI inflows on the local economies of the US states that receive most of the FDI inflows in the country (Axarloglou \& Pournarakis, 2007). A study by Wijeweera, Dollery, and Clark (2007) analyzed the relationship between the corporate tax rates and foreign direct investment in the United States (Wijeweera, Dollery, \& Clark, 2007). Chung and Alcácer (2002) examined whether and when state technical capabilities attract foreign investment in manufacturing from 1987-1993 (Chung \& Alcácer, 2002). Head, Ries, and Swenson (1995) show that there do exist agglomeration effects of Japanese manufacturing firms in the United States (Head, Ries, \& Swenson, 1995).

The empirical literature related to the state based determinant of FDI employment in the U.S. is limited. In evaluating the effects of FDI on the local economies, economists focus primarily on the performance of foreign-owned subsidiaries operating in the U.S.. It is already known that the establishment of a new foreign subsidiary or the expansion of an already existing one leads to higher employment and wages (Axarloglou, 2005). Reserchers identified link between job growths in the U.S. economy during a period of increasing foreign direct investment flow. The economic impact on U.S. employment due to FDI is evident, as are linkages among the various benefits due to the inward flow of FDI (Craig, 2008).

Acording to Axarloglou and Pournarakis in the last two decades, various US states offered strong 
economic incentives in an effort to attract FDI inflows, with the hope that FDI would stimulate local economies (Axarloglou \& Pournarakis, 2005). Axarloglou, Casey, and Han (2006) analyzed the effects of FDI inflows in local economies across US states. The empirical results point out that the US economy benefits from FDI inflows in manufacturing both in terms of employment and real wages. Overall, FDI inflows have a positive and in several cases statistically significant impact on local employment and wages. However, these effects vary across US states. In some states, such as California, Michigan, Ohio, and Pennsylvania, FDI inflows appear to expand both employment and wages while in others, like Florida, Georgia, and Virginia appear to depress both employment and wages. Finally, in several US states, such as in Connecticut, Delaware, Kentucky, and Louisiana, FDI inflows have mixed effects on local labor markets, with predominantly negative effects on local employment and expanding effects on local wages. There is evidence that these results are due to the industry composition of FDI inflows across states. FDI inflows in printing and publishing, fabricated metals, industrial machinery, and transportation equipment have positive employment and wages effects, while FDI inflows in furniture and leather have negative effects (Axarloglou, Casey, \& Han, 2006).

The studies by Borstorff, Collum, and Newton relate to FDI in the southern U.S., specifically automobile FDI in Alabama and describe state-specific features of southern states in recruiting foreign investment bringing the employment opportunities (Borstorff, Collum, \& Newton, 2007).

Ajaga and Nunnen show an analysis complements the regression analysis of Mullen and Williams and the Markov chain approach of Bode and Nunnenkamp and presents strong evidence of favorable FDI effects on output and employment at the level of US states (Ajaga \& Nunnen, 2008).

Bode and Nunnenkamp (2007) investigated the effects of inward FDI on per-capita income and growth of the US states since the mid-1970s. This study analyzed the long-run relationships between inward FDI and economic outcomes in terms of value added and employment at the level of US states (Bode \& Nunnenkamp, 2007). The study found that employment-intensive FDI, concentrated in richer states, has been conducive to income growth, while capital-intensive FDI, concentrated in poorer states, has not.

\section{Data Sources and Variables}

In order to test the implications of our models, we collected a panel of aggregate data on foreign direct investment on all U.S. states, excluding the district of Columbia. The entire data set include 50 states for which foreign direct investment and all other relevant variables are reported over the 1997-2007 period.

In the United States, the Bureau of Economic Analysis (BEA), a section of the U.S. Department of Commerce, is responsible for collecting economic data related to FDI flows. Monitoring this data is very helpful in trying to determine the impact of FDI on the overall economy, but is especially helpful in evaluating states and industry segments. The data on stock of FDI are from the U.S. Department of Commerce, Bureau of Economic Analysis².

The real per capita disposable income is measured as the nominal per capita disposable income deflated by the GDP deflator in constant (2000) U.S. dollars. The real per capita taxes is measured by dividing the real state tax revenue by the state population. The nominal tax revenue for states is from various issues of the Annual Survey of State Government Finances published by the U.S. Department of Commerce ${ }^{3}$.

\footnotetext{
2 The U.S. Department of Commerce, Bureau of Economic Analysis (BEA) (Retrieved from http://www.bea.gov).

${ }^{3}$ State Government Finances... Census Bureau (Retrieved from http://www.census.gov/govs/state/).
} 
The nominal tax revenue was deflated by the GDP deflator to derive the real state tax revenue. The data on state population are from the U.S. Census Bureau ${ }^{4}$. The real per capita expenditure on education is measured by dividing the real state education expenditure by the state population. The nominal education expenditure for states is from various issues of the Annual Survey of State Government Finances published by the U.S. Department of Commerce ${ }^{5}$. The nominal education expenditure was deflated by the GDP deflator to derive the real state education expenditure.

The share of scientists and engineers in the workforce, a proxy for labor quality, is collected from the National Science Foundation, Division of Science Resources Statistics, Science and Engineering Indicators $2010^{6}$. The data on FDI related employment are collected from the Bureau of Economic Analysis ${ }^{7}$, while the data on state employment are collected from the U.S. Department of Labor, Bureau of Labor Statistics ${ }^{8}$. The information on real research and development expenditure is collected from the National Science Foundation, Division of Science Resources Statistics, Science and Engineering Indicators ${ }^{9}$.

The data on the average wage and total state employment are collected from the U.S. Department of Labor, Bureau of Labor Statistics ${ }^{10}$. Following Coughlin, Terza, and Arromdee (1991), the manufacturing density variable is measured as the manufacturing employment per square mile of state land excluding federal land. The data on manufacturing employment are collected from the U.S. Department of Labor, Bureau of Labor Statistics ${ }^{11}$. The information on union membership is collected from Union Membership and Coverage Database from the CPS ${ }^{12}$ maintained by Barry Hirsch (Georgia State University) and David Macpherson (Trinity University). The data on state unemployment rate are collected from the U.S. Department of Labor, Bureau of Labor Statistics ${ }^{13}$.

\section{Model Specification}

Drawing on the existing empirical literature in this area, we specify the following model:

$$
\begin{aligned}
\text { FDIEMP }= & \beta_{0}+\beta_{1} E D U+\beta_{2} R F D I+\beta_{3} G D P G R+\beta_{4} P C E X P+\beta_{5} P C T A X+\beta_{6} R W A G E+\beta_{7} U N I O N \\
& +\beta_{8} S A E+\beta_{9} M A N D E N+\beta_{10} R N D+\beta_{11} H W Y+\varepsilon
\end{aligned}
$$

where:

FDIEMP: FDI related employment;

EDU: Educational attainment;

RFDI: Real FDI stock;

GSPGR: Real GSP growth rate;

PCEXP: Real per capita exports;

PCTAX: Real per capita taxes;

RWAGE: Real wage;

\footnotetext{
4 The U.S. Census Bureau (Retrieved from http://www.census.gov).

${ }^{5}$ Ibid 4.

6 Science and Engineering Indicators: 2010 (Retrieved from http://www.nsf.gov/statistics/seind10/).

7 The U.S. Department of Commerce, Bureau of Economic Analysis (BEA) (Retrieved from http://www.bea.gov).

8 The U.S. Department of Commerce, Bureau of Economic Analysis (BEA) (Retrieved from http://www.bls.gov).

${ }^{9}$ National Science Foundation, Division of Science Resources Statistics, Science and Engineering Indicators (Retrieved from http://www.nsf.gov/statistics/seind10/).

10 The U.S. Department of Labor, Bureau of Labor Statistics (Retrieved from http://www.bls.gov).

11 Ibid 11.

12 Union Membership and Coverage Database from the CPS (Retrieved from http://www.unionstats.com/).

13 Ibid 11.
} 
UNION: Union membership (share of workers who are members of labor unions);

$S A E$ : Share of scientists and engineers in the labor force;

MANDEN: Manufacturing density;

$R N D$ : Real research and development expenditure;

$H W Y$ : Highway mileage.

$F D I E M P_{i t}$ represents FDI related employment in state $i$ in year $t ; E D U_{i t}$ is the real per capita expenditure on education in state $i$ in year $t$; $R F D I_{i t}$ represents real FDI stock in state $i$ in year $t$; GSPGR $R_{i t}$ stands for real gross state product growth rate in state $i$ in year $t$; $P C E X P_{i t}$ is real per capita exports in state $i$ in year $t$; PCTAX $X_{i t}$ symbolizes real per capita taxes in state $i$ in year $t ; R W A G E_{i t}$ is real wage in state $i$ in year $t$; UNION $N_{i t}$ represents share of workers who are members of Labor Unions in state $i$ in year $t$; $S A E_{i t}$ stands for share of scientists and engineers in the labor force in state $i$ in year $t ; M A N D E N_{i t}$ represents manufacturing density in state $i$ in year $t$; $R N D_{i t}$ relates to real research and development expenditure in state $i$ in year $t ; H W Y_{i t}$ stands for highway mileage in state $i$ in year $t$.

Our first variable, the real per capita expenditure on education is expected to have a positive effect on foreign direct investment employment. Therefore, we would expect that $\beta_{1}>0$. Our second variable, the real FDI stock is expected to have a positive effect on FDI employment. Therefore, we would expect that $\beta_{2}>0$. Our third variable, the real gross state product growth rate is expected to have positive effect on FDI employment. Therefore, we would expect that $\beta_{3}>0$.

The fourth variable, the real per capita exports is expected to be positive. The fifth variable, the real per capita state taxes usually deter FDI flows and, therefore, is expected to be negatively related to foreign direct investment employment, thus, we would expect that $\beta_{5}<0$. The sixth variable, real estate per capita wages is a measure of market demand in a state and is expected to be positively related to foreign direct investment employment. Therefore, a priori, we would expect that $\beta_{6}>0$. The next variable, unionization of the workforce is expected to be related positively to foreign direct investment employment. Thus, we would expect that $\beta_{7}>$ 0 .

The eighth variable, the share of scientists and engineers in the workforce, a proxy for labor quality is expected to have a positive effect on foreign direct investment employment. Therefore, we would expect that $\beta_{8}>0$. The manufacturing density is expected to be related positively to foreign direct investment employment. Therefore, we would expect that $\beta_{9}>0$. As Coughlin, Terza, and Arromdee (1991) and Head, Ries, and Swenson $(1995,1999)$ point out, manufacturing density could also be used as a proxy for agglomeration economies. States with higher densities of manufacturing activity is expected to attract more foreign direct investment because the foreign investors might be serving existing manufacturers. Our tenth variable, the real research and development expenditure is expected to have a positive effect on foreign direct investment employment. Therefore, we would expect that $\beta_{10}>0$. Highway mileage is an indicator of infrastructure which expected to be positively correlated with foreign direct investment employment. Therefore, we would expect that $\beta_{11}>0$.

\section{Empirical Results}

The results of our empirical analysis are presented in Table 2 based on the 11 independent variables included in equation (1). All the variables presented in Table 2 are expressed in logarithm and the coefficient of each variable can be interpreted as elasticities. The results of the study imply that FDI employment in the U.S. 
is strongly influenced by the state spending on education. The coefficient of this variable is positive and statistically significant at the $1 \%$ level of significance. The real stock of FDI has a positive and statistically significant effect on FDI related employment. The results of the study suggest that FDI employment is strongly correlated with the real FDI stock in the U.S. This could be due to the fact that the states with high level of FDI employment also have larger FDI stock. Real per capita exports have the positive sign and are statistically significant at the $1 \%$ level. Usually, higher FDI stock and employment result in higher state exports.

Table 2

Determinants of FDI Related Employment in the United States, 1990-2007 Panel Least Squares Estimates, Dependent Variable: FDI Related Employment

\begin{tabular}{lcr}
\hline Variable & Coefficient & $t$-statistic \\
\hline Constant & $-248.2263^{* * * *}$ & -13.34 \\
Education & $1.6966^{* * *}$ & 9.08 \\
Real FDI stock & $1.8515^{* * *}$ & 9.04 \\
Real GSP growth rate & $-3.2924^{* * *}$ & -16.23 \\
Real per capita exports & $0.0603^{* * *}$ & 5.11 \\
Real per capita taxes & $-0.0600^{* * *}$ & -10.37 \\
Real wages & $15.5267^{* * *}$ & 14.13 \\
Unionization & $2.5801^{* * *}$ & 7.79 \\
Scientists and engineers & -0.1157 & -0.68 \\
Manufacturing density & 0.0003 & 0.03 \\
Real research and development expenditure & 0.0000 & 0.24 \\
Highway mileage & $9.9975^{* * *}$ & 7.13 \\
Adjusted $R^{2}$ & 0.8662 & \\
Number of periods & 18 & \\
Number of cross-sections & 50 & \\
Number of observations & 900 & \\
\hline
\end{tabular}

Note. ${ }^{* * *}$ indicates the statistical significant at the $1 \%$ level.

Real GSP growth rate has the unexpected negative sign and it is statistically significant at the $1 \%$ level. It can be explained by the fact that many foreign investors choose the southern part of the U.S. as a desirable location for their FDI. The southern U.S. states has become more aggressive in recruiting foreign investment by providing incentives to attract investments and communicating the unique advantages they offer to foreign companies.

The real per capita taxes have the expected negative sign and it is statistically significant at $1 \%$ level. This finding is also consistent with the findings of previous studies. Real wages have the positive sign and it is statistically significant at $1 \%$ level. It is well known that foreign companies investing in U.S. not only provide jobs, but also provide relatively high-paying jobs what constitutes important determinant of FDI employment. Unionization variable has an expected positive sign, and it is statistically significant at the $1 \%$ level of significance.

Surprisingly, the share of scientists and engineers in the workforce has an unexpected negative sign. It can be related to the fact that the labor force is relatively more productive and skilled in urban than in rural areas. Manufacturing density variable has the expected positive sign. This variable is also expected to capture the agglomeration economies and we can guess that the denser the manufacturing activity is in a given state, the more likely higher foreign direct investment employment will be. However, current results reveal that the 
southeast region in the U.S. stem from relatively high manufacturing density. Highway mileage represents infrastructure level in the state and it is definitely positively correlated with the FDI employment at the 1\% level of significance.

\section{Conclusions}

This paper investigates locational determinants of the inward FDI among 50 states of the United States. In order to test the implications of our models, we collected a panel of aggregate data on foreign direct investment on all U.S. states, excluding the district of Columbia. The entire data set includes 50 states for which foreign direct investment and all other relevant variables are reported over the 1997-2007 period. US policymakers obviously expect FDI inflows to help improve income and employment prospects in the economy.

Inward FDI represents an integral part of the U.S. economy. Most of the foreign investment in the United States comes from the European developed economies. These investments are predominately in the manufacturing sector and accounts for very high percentage of foreign direct investment in the United States. U.S. affiliates of foreign companies in the manufacturing industry are the largest contributor of FDI employment in the U.S. economy. In 2009, manufacturing employment accounted for $36.3 \%$ of total FDI employment. The next large industry outside the manufacturing for employment by U.S. affiliates of foreign companies was retail trade. The retail trade industry accounted for $10.9 \%$ of total FDI employment followed by wholesale $9.7 \%$ along with finance and information consecutively accounting for $6.8 \%$ and $6.4 \%$ of total FDI employment. The leading states in foreign direct investment employment are California, Texas, Ohio, Pennsylvania, Illinois, North Carolina, New York, and New Jersey. The southern U.S. states have become more aggressive in recruiting foreign investment by providing incentives to attract investments.

It is well known that foreign companies investing in the United States not only provide jobs, but also offer relatively high-paying jobs what constitutes important factor influencing to high FDI employment and contributing to employment in the U.S. economy. Findings of our research show that real wages variable has the positive sign and it is statistically significant at the $1 \%$ level.

The next important factor the state highway mileage representing infrastructure is positively related to the FDI employment at the $1 \%$ level of significance. Among other findings, unionization variable, as expected is statistically significant at the $1 \%$ level of significance. It is well known that the degree of unionization within U.S. affiliates of foreign companies is relatively higher in comparison with domestic companies.

The real stock of FDI has a positive and statistically significant effect on FDI related employment. This could be due to the fact that the states with high level of FDI stocks also have larger related employment. The education has the expected positive sign and it is statistically significant at the $1 \%$ level. It can be concluded that for states to attract more investment is to spend more on educations and research and development activities.

The real per capita taxes has the expected negative sign and it is statistically significant at $1 \%$ level. This finding is also consistent with the findings of previous studies. Given that the current results suggest that state government taxation negatively affect foreign direct investment, state governments may consider providing more fiscal incentives to foreign investors in order to attract more foreign direct invest to their states.

Real state growth rate has the unexpected negative sign and it is statistically significant at the $1 \%$ level. It can be explained by the fact that many foreign investors choose the southern part of the U.S. as a desirable location for their FDI. The southern U.S. states has become more aggressive in recruiting foreign investment by 
providing incentives to attract investments and communicating the unique advantages they offer to foreign companies. It could be related to the fact that employment-intensive FDI, concentrated in richer states, has been conducive to growth, while capital-intensive FDI, concentrated in poorer states, has not. Additionally, according to Alfaro, foreign direct investments in the primary sector tend to have a negative effect on growth and employment, while investment in manufacturing tend to have a positive one, while the evidence from the service sector is ambiguous (Alfaro, 2003). Surprisingly, the share of scientists and engineers in the workforce has an unexpected negative sign. It can be related to the fact that the labor force is relatively more productive and skilled in urban than in rural areas.

Our findings indicate that the importance of selected variables in evaluating the effects of FDI flow on state employment. Also, they emphasize the need for U.S. to selectively target FDI in specific states and industries and make host governments aware of importance of promotional effort to attract foreign direct investment and stimulate employment and growth at the state level contributing to overall output and employment growth in the U.S. economy. Encouraging more FDI and expanding the number of countries investing in the United States can lead potentially to higher employment and higher economic growth.

\section{References}

Ajaga, E., \& Nunnen, P. (2008). Inward FDI, value added and employment in US States: A panel cointegration approach. Kiel Working Paper No. 1420.

Alfaro, L. (2003). Foreign direct investment and growth: Does the sector matter? Harvard University, Harvard Business School, Working Paper.

Asheghian, P. (2004). Determinants of economic growth in the United States: The role of foreign direct investment. The International Trade Journal, 18(1), 63-83.

Axarloglou, K. (2005). What attracts foreign direct investment inflows in the United States. The International Trade Journal, 19(3), 285-308.

Axarloglou, K., \& Pournarakis, M. (2005). Do All Foreign Direct Investments Benefit the Local Economy. The World Economy (Second Revision), 30, 1-2.

Axarloglou, K., \& Pournarakis, M. (2007). Do all foreign direct investment inflows benefit the local economy? The World Economy, 30(3), 424-432.

Axarloglou, K., Casey, W., \& Han, H. (2006). Inward foreign direct investments in the US: An empirical analysis of their impact on state economies. Eastern Economic Journal, 37(4), 508-529.

Bartik, T. J. (1985). Business location decisions in the United States: Estimates of the effects of unionization, taxes, and other characteristics of states. Journal of Business \& Economic Statistics, American Statistical Association, 3(1), 14-22.

Bode, E., \& Nunnenkamp, P. (2007). Does foreign direct investment promote regional development in developed countries? A Markov Chain Approach for US States. Kiel Working Paper No. 1374.

Borstorff, P. C., Collum, T. H., \& Newton, S. (2007). FDI in the southern U.S.: A case study of the Alabama and the automotive sector allied academies international conference. Proceedings of the International Academy for Case Studies, Jacksonville, USA.

Borstorff, P. C., Collum, T. H., \& Newton, S. (2009). King of the hill: Competing for foreign direct investment in "Dixie”. Journal of the International Academy for Case Studies, 15(8).

Bureau of Economic Analysis. (2012a). Foreign direct investment in the U.S.: Balance of payments and direct investment position data. Retrieved December 18, 2012, from http://www.bea.gov/international/di1fdibal.htm

Bureau of Economic Analysis. (2012b). Foreign direct investment in the United States (FDIUS). Retrieved December 18, 2012, from http://www.bea.gov/international/dilfdiop.htm

Carlton, D. W. (1983). The location and employment choices of new firms: An econometric model with discrete and continuous endogenous variables. The Review of Economics and Statistics, 65(3), 440-449.

Chowdhury, A., \& Mavrotas, G. (2006). FDI and growth: What causes what? The World Economy, 29(1), 9-19. 
Chung, W., \& Alcácer, J. (2002). Knowledge seeking and location choice of foreign direct investment in the United States. Management Science, 48(12), 1534-1554.

Cletus, C. C., Terza, J. V., \& Arromdee, V. (1987). State characteristics and the location of foreign direct investment within the United States: Minimum chi-square conditional logit estimation. Working papers Series. Working Paper 1987-006B.

Coughlin, C. C., Terza, J. V., \& Arromdee, V. (1991). State characteristics and the location of foreign direct investment within the United States. Review of Economics and Statistics, 68, 67-83.

Craig, H. M. (2008). Foreign direct investment (FDI) and job growth in the United States: An economic impact study. USA: North Central University.

Head, C. K., Ries, J. C., \& Swenson, D. L. (1995). Agglomeration benefits and location choice: Evidence from Japanese manufacturing investments in the United States. Journal of International Economics, 38, 223-247.

Head, C. K., Ries, J. C., \& Swenson, D. L. (1999). Attracting foreign manufacturing: Investment promotion and agglomeration. Regional Science and Urban Economics, 29, 197-218.

Payne, D., \& Yu, F. (2011). Foreign direct investment in the United States. ESA Issue Brief \#02-11, U.S. Department of Commerce, Economics and Statistics Administration.

Wijeweera, A., Dollery, B., \& Clark, D. (2007). Corporate tax rates and foreign direct investment in the United States. Applied Economics, 39(1), 109-117. 